\title{
Dvě významná výročí jihomoravské archeologie. 180 let od narození Františka Vildomce. 20 let od úmrtí Vědomila Vildomce
}

\author{
Two significant anniversaries of South Moravian archaeology. 180th \\ birth anniversary of František Vildomec. 20th death anniversary of \\ Vědomil Vildomec
}

\section{Petr Menšík}

V roce 2018 si připomínáme významná výročí dvou jihomoravských archeologů Františka a Vědomila Vildomců. František Vildomec se narodil 6. února 1978 ve Svatošově u Tišnova. Od patnácti let byl studentem učitelského ústavu v Brně a v roce 1897 si podal žádost na místo učitele, které mu bylo přiděleno v Hostimi na Znojemsku. Na svou dobu měl radikální názory ohledně vztahu k církvi. Na konci 19. století se seznámil s hnutím Volná myšlenka, které se zabývalo možnou odlukou od církve. V roce 1908 také z této instituce vystoupil a byl v oblasti Rakouska-Uherska jediným takto vyučujícím učitelem. Tento směr jeho myšlenek byl prosazen poté zejména v roce 1921, kdy se učitelé v okresu Moravské Budějovice usnesli na odluce školy od církve. V roce 1922 byl jmenován řídícím učitelem školy v Boskovštejně. V roce 1919 se oženil s Eugenií (rozenou Stejskalovou). V roce 1920 se jim narodil syn Věroboj a v roce 1921 syn Vědomil. Roku 1898 potkává významnou jihomoravskou osobnost notáře Františka Palliardiho. Od roku 1906 společně prováděli řadu terénních výzkumů na území obcí jako např. Boskovštejn, Horní Dunajovice, Jevišovice, Střelice nebo Těšetice. Po smrti Palliardiho (1861-1922) ve výzkumech pokračoval a vytvořil rozsáhlou archeologickou sbírku, která mu umožnila rozdělit kulturu s moravskou malovanou keramikou do šesti stupňů. První část sbírky byla předána před druhou světovou válkou Moravskému zemskému muzeu, druhá byla prodána po smrti jeho syna Vědomila. V současnosti je sbírka uložena a zpřístupněna na zámku v Jevišovicích. Kromě archeologie František rád cvičil s dětmi divadlo, hrál na celou řadu hudebních nástrojů, stal se jednatelem, předsedou nebo funkcionářem řady spolků nebo založil a vedl obecní kroniku. Kromě toho často přednášel a psal zejména do regionálního tisku. V roce 1963 byl jmenován čestným občanem Hlubokých Mašůvek za mnohaletou práci na místním archeologickém výzkumu. V témže roce mu prezident Antonín Novotný udělil státní vyznamenání Za vynikající práci. A nakonec v roce 1969 jej vláda našeho státu 


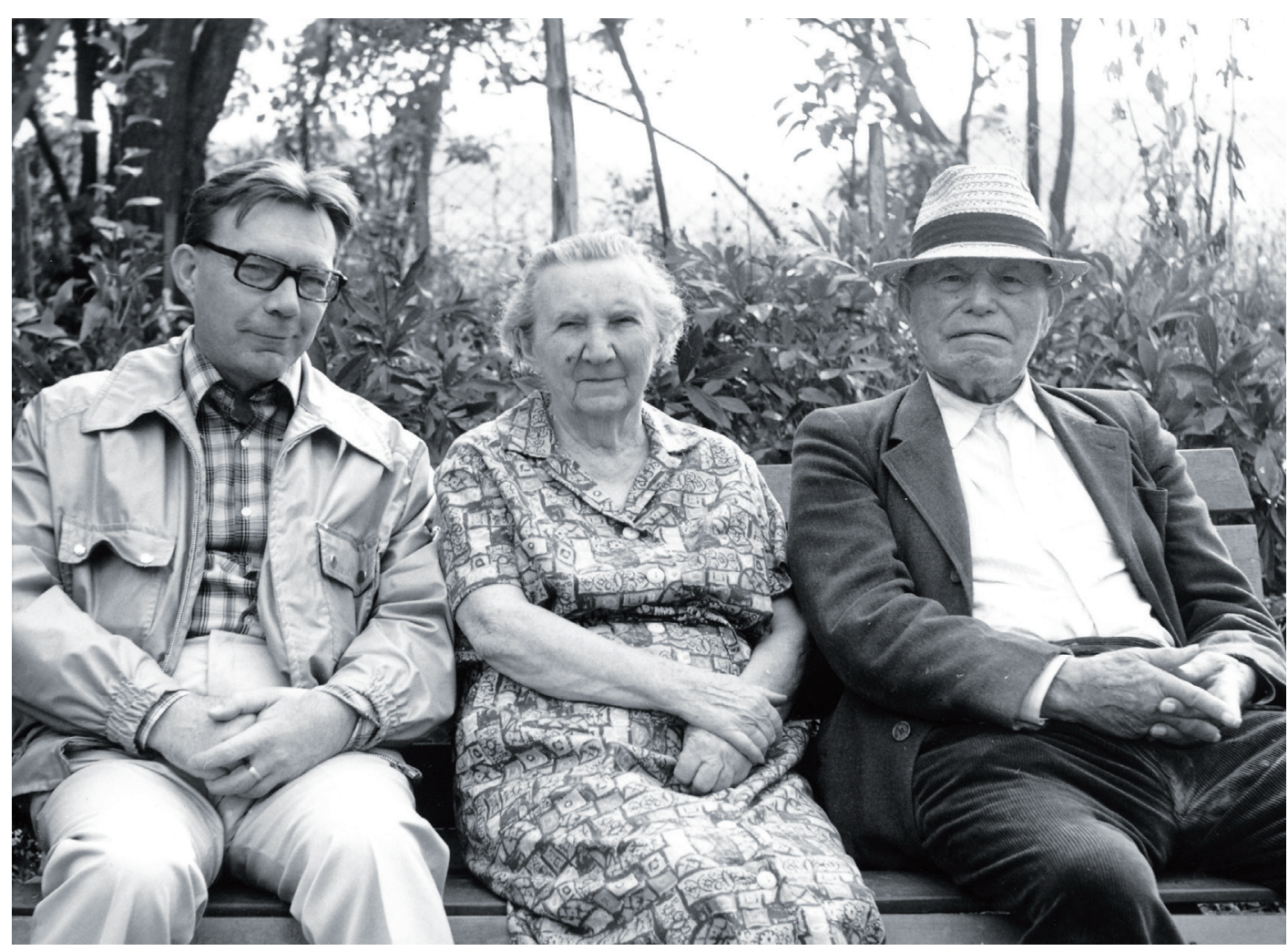

Obr. 1: Posezení na Boskovštejně. Vědomil, Evženie a František Vildomcovi.

Fig. 1: A gathering in Boskovštejn. Vědomil, Evženie and František Vildomec.

jmenovala zasloužilým umělcem. František Vildomec zemřel ve věku 97 let dne 3. 11. 1975 (Podborský 2005; Vildomcová 2012).

Vědomil Vildomec se narodil 27. září 1921 jako mladší syn řídícího učitele a archeologa Františka Vildomce. Po hektických letech studia před začátkem a zejména během začátku druhé světové války byl nejprve pomocným učitelem a od roku 1944 „totálně nasazen“ jako pomocný dělník do Hradce Králové. Ke studiu na vysoké škole v Brně mohl nastoupit až v roce 1945 a titul PhDr. získal v roce 1950. Díky nepřízni režimu vystřídal řadu učitelských míst, avšak v roce 1961 se mu podařilo nastoupit jako odborný pracovník do Jihomoravského muzea ve Znojmě. Zde působil až do odchodu do dů- chodu, od roku 1969 jako ředitel této instituce. V roce 1967 se také oženil s Miluší Sobotkovou a v roce 1969 se jim narodil syn Vědomil. Kromě osvětové činnosti v pozici učitele a pracovníka muzea je spoluautorem významné publikace Pravěk Znojemska (1972: společně s V. Podborským). S prof. Podborským spolupracoval také na několika archeologických výzkumech, zejména poté na systematickém výzkumu neolitické lokality u Těšetic-Kyjovic. Významně se taktéž podílel na celé řadě výstav a př́ípravě expozic Jihomoravského muzea (Kovárnik 1999, 1; Podborský 2005; Vildomcová 2012).

Pro mne je významné výročí úmrtí Vědomila Vildomce také tím, že se jednalo o manžela sestry mé babičky. Jako malý jsem si hrával 


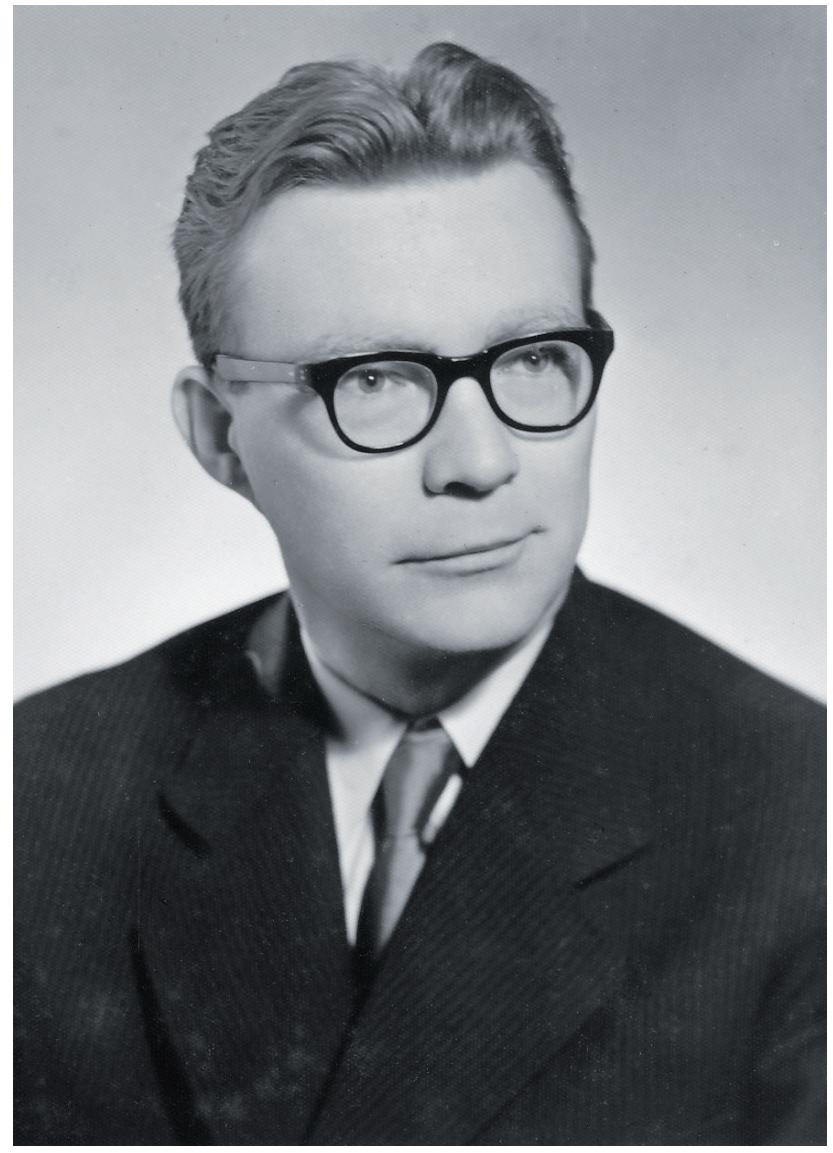

Obr. 2: Vědomil Vildomec pravděpodobně v 50. letech 20. století.

Fig. 2: Vědomil Vildomec probably in the 1950s.

na boskoštejnské vile a zahradě při návštěvách tety Miluše Vildomcové. Jako malý si matně vzpomínám i na samotného Vědomila Vildomce z počátku 90. let. Po probuzení zájmu o archeologické památky jsem s úžasem navštěvoval uloženou archeologickou sbírku z období nejen lengyelské kultury, v jejímž popředí stála známá venuše z Hlubokých Mašůvek. Jmenovat však lze i další naprosté unikáty: střelickou vázu se čtyřmi vypíchanými lidskými postavami nebo například bronzovou sponu s kuželkami a řadu dalších exponátů. Sbírku shromáždil František Vildomec soukromou badatelskou činností v letech 1929-1939. Nic velkolepějšího jsem z období této „malované civilizace“ již od té doby neviděl. Až dnes dokáži pochopit nejen význam z hlediska poznání naší minulosti, ale také množství vynaložené práce při systematickém zpracování archeologického materiálu a jeho restaurování. V dnešních dnech mám to štěstí seznamovat $\mathrm{s}$ výjimečností tohoto souboru své studenty na katedře archeologie v Plzni i v rámci výuky studentů na Univerzitě třetího věku.

Čest jejich památce. 


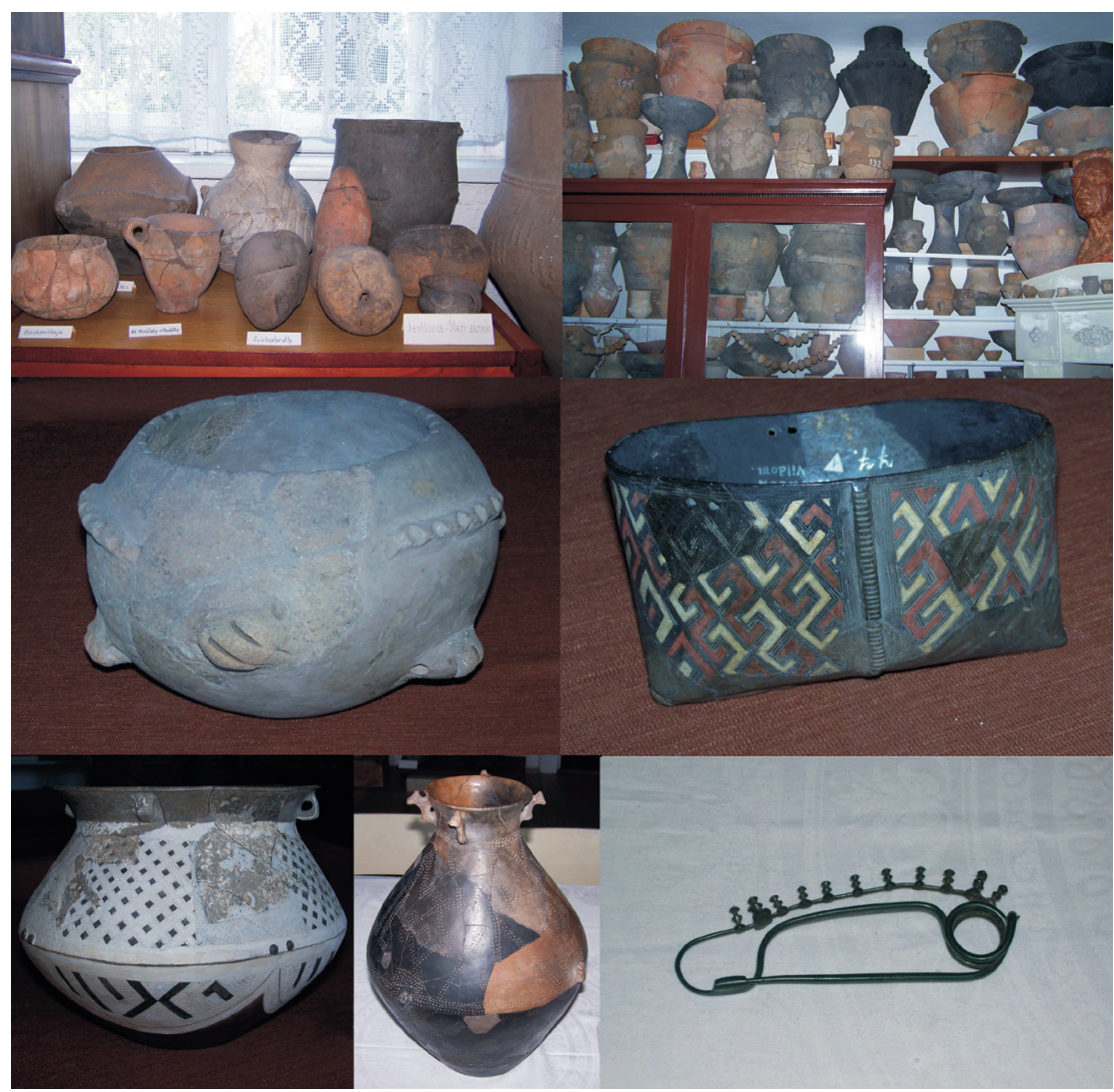

Obr. 3: Několik ukázek nálezů z archeologické sbírky Františka a Vědomila Vildomcových na Boskovštejně. Foto P. Menšík v roce 2005.

Fig. 3: Several examples of finds from the archaeological collection of František and Vědomil Vildomec in Boskovštejn. Photo P. Menšík in 2005.

\section{Literatura:}

Kovárnik, J. 1999: Zemřel PhDr. Vědomil Vildomec, Znojemské listy 8/1 (07. 01. 1999), 1.

Podborský, V. 2005: František Vildomec (6. 2. 1878-3.

11. 1975) venkovský učitel, vlastivědný pracovník a věhlasný archeolog. Vědomil Vildomec (27. 9.
1921-28. 12. 1998) syn věhlasného archeologa, kantor, muzejník, archeolog a kulturně-osvětový pracovník. Brno.

Podborský, V. - Vildomec, V. 1972: Pravěk Znojemska. Znojmo.

Vildomcová, M. 2012: Volnomyšlenkář aneb jak to bylo. Třebíč.

\section{PhDr. Petr Menšík, Ph.D.}

- Katedra archeologie, Západočeská univerzita v Plzni Sedláčkova 15 CZ 30614 Plzeň

pmensik@kar.zcu.cz 